\title{
Primary non-compliance with prescribed medication in primary care
}

\author{
P H G Beardon, M M McGilchrist, A D McKendrick, D G McDevitt, T M MacDonald
}

\begin{abstract}
Objective-To determine the rate of patients not redeeming their prescriptions (primary noncompliance) and assess the factors influencing this.

Design-Observational study comparing copies of prescriptions written by general practitioners with those dispensed by pharmacists and subsequent case record review.
\end{abstract}

Setting-A large rural general practice in Tayside.

Subjects-All 4854 patients who received prescriptions (20 921) written between January 1989 and March 1989.

Main outcome measures-The rate of nonredemption of prescriptions.

Results-Seven hundred and two patients (14.5\%) did not redeem $1072(5 \cdot 2 \%)$ prescriptions during the study period, amounting to $11.5 \%$ of men and $16.3 \%$ of women. Non-redemption was highest in women aged 16-29 (27.6\% of women) and men aged 40-49 (18.3\% of men). Of prescriptions issued to women for oral contraceptives $\mathbf{2 4 . 8 \%}$ were not redeemed during the study period. In those who redeemed prescriptions $17 \%$ were not exempt from prescription charges compared with $33 \%$ of patients who failed to redeem them. The non-redemption rate was highest for prescriptions issued at the weekends, although this was a small proportion of all prescribing. Prescriptions issued by trainee general practitioners were also less likely to be redeemed.

Conclusions-Non-redemption varies with age, sex, general practitioner, exemption status, and with day of the week the prescription was written. Observational studies of drug exposure can be more accurately estimated from dispensing rather than prescribing data.

\section{Medicines Monitoring Unit, Department of Pharmacology and Clinical Pharmacology, Ninewells Hospital and Medical School, Dundee DD1 9SY \\ P H G Beardon, research fellow \\ M M McGilchrist, senior computer programmer D G McDevitt, professor of clinical pharmacology T M MacDonald, senior lecturer}

Carnoustie Health Centre, Carnoustie, Tayside DD7 7RB

A D McKendrick, general practitioner

Correspondence to:

Dr MacDonald.

$B M f 1993 ; 307: 846-8$

\section{Introduction}

Non-compliance with prescribed medication is an important problem in clinical practice which may cause treatment to fail. ${ }^{1-3}$ Primary non-compliancepatients failing even to redeem their prescriptionshas been found for $6-20 \%$ of all primary care prescriptions, ${ }^{46}$ although previous studies have been small. The purpose of this study was to quantify the rate of prescription non-redemption in primary care and to assess the influence on this of patient age, sex, social class, prescribing general practitioner, and type of drug prescribed.

\section{Methods}

Copies of all prescriptions written over three months from 1 January to 31 March 1989 were obtained from Carnoustie Health Centre in Tayside, which comprised seven principals and two trainees. Copies were obtained by using specially printed prescription pads, with carbonless copies inserted, or by using carbonless duplicate computer paper inserted under the computer prescription form. These copies were sent to the medicines monitoring unit at weekly intervals and data entered on to computer. Patients were coded using their community health number, a unique identifier allocated to all people who register with a general practitioner in Tayside, which combines the date of birth and a sex indicator. Drugs were coded using the system developed by the Prescription Pricing Authority in England. Other data recorded were the date of prescription, a code for the issuing general practitioner, and whether or not the prescription was a repeat (defined on the third or subsequent issue of a prescription for the same episode of illness).

Prescriptions redeemed in Tayside were retrieved from the pharmacy practice division of the Common Services Agency for the period January to April 1989 for all prescriptions issued by the practice. April was included to ensure that prescriptions submitted late to a pharmacy were captured. Prescriptions written from January to March 1989 were matched to the redeemed originals and any unmatched duplicates analysed. Prescriptions for which the community health number could not be ascertained were omitted from the analysis, as were prescriptions which had been redeemed but for which no duplicates were available. The exemption status of anyone redeeming a prescription was recorded from the self certificated data on the reverse of the prescription form.

The general practice records of patients who did not redeem prescriptions were examined to determine which factors may have influenced their behaviour, to ascertain whether the prescription was dispensed elsewhere, and to check on exemption status.

The case notes of 45 patients who had redeemed their prescriptions and whose exemption status was known were abstracted blindly to ascertain the accuracy of determining exemption status from case records. Statistical differences in non-redemption rates between groups were calculated using the $\chi^{2}$ test. Confidence intervals for proportions were calculated as described by Wonnacott and Wonnacott. ${ }^{7}$

\section{Results}

The practice list consisted of 5930 women and 5570 men. Of these, $2999(51 \%)$ women and 1855 (33\%) men received a total of 13457 and 7464 prescription items respectively in the three month period (4.5 items per woman and 4.0 per man who received prescriptions). It was not possible to match 745 items prescribed to women and 327 to men with dispensed items. These were treated as unredeemed and were analysed in detail. A further 387 prescription forms (483 items) for which there were no carbon copies were received from the prescription pricing division; these were excluded from the analysis.

Overall $702(14.5 \%)$ of the 4854 patients who were issued prescriptions failed to have 1072 items dispensed ( $5 \cdot 2 \%$ of the 20291 written), giving an average of 1.5 non-redeemed items per person. This was lowest in those aged 15 or under, increasing with age to 2.3 in 
TABLE I-Mean number of non-redeemed items per patient who did not redeem at lest one prescription item

\begin{tabular}{lccc}
\hline Age & $\begin{array}{c}\text { No of items } \\
\text { not redeemed }\end{array}$ & $\begin{array}{c}\text { No of patients } \\
\text { not redeeming a } \\
\text { prescription item }\end{array}$ & $\begin{array}{c}\text { No of } \\
\text { prescription } \\
\text { items per patient }\end{array}$ \\
\hline$\leqslant 15$ & 58 & 49 & $1 \cdot 2$ \\
$16-29$ & 189 & 157 & $1 \cdot 2$ \\
$30-39$ & 179 & 129 & $1 \cdot 4$ \\
$40-49$ & 153 & 110 & $1 \cdot 4$ \\
$50-59$ & 153 & 91 & $1 \cdot 7$ \\
$60-69$ & 124 & 70 & $1 \cdot 8$ \\
$\geqslant 70$ & 216 & 96 & $2 \cdot 3$ \\
\hline Total & 1072 & 702 & $1 \cdot 5$ \\
\hline
\end{tabular}

TABLE II-Age and sex distribution for people receiving prescriptions and the rate of non-redemption in each

\begin{tabular}{|c|c|c|c|c|c|c|c|c|}
\hline \multirow[b]{2}{*}{ Age } & \multicolumn{4}{|c|}{ No of patients } & \multicolumn{4}{|c|}{ No of prescription items } \\
\hline & Men & $\begin{array}{l}\text { No }(\%) \text { not } \\
\text { redeeming }\end{array}$ & Women & $\begin{array}{l}\text { No (\%) not } \\
\text { redeeming }\end{array}$ & Men & $\begin{array}{l}\text { No }(\%) \text { not } \\
\text { redeemed }\end{array}$ & Women & $\begin{array}{l}\text { No }(\%) \text { not } \\
\text { redeemed }\end{array}$ \\
\hline$\leqslant 15$ & 326 & $21(6 \cdot 4)$ & 388 & $28(7 \cdot 2)$ & 751 & $26(3 \cdot 5)$ & 827 & $32(3.9)$ \\
\hline $16-29$ & 281 & $29(10 \cdot 3)$ & 463 & $128(27 \cdot 6)$ & 599 & $35(5 \cdot 8)$ & 1016 & $154(15 \cdot 2)^{\star}$ \\
\hline $30-39$ & 201 & $34(16.9)$ & 386 & $95(24 \cdot 6)$ & 475 & $48(10 \cdot 1)$ & 1090 & $131(12 \cdot 0)$ \\
\hline $40-49$ & 218 & $40(18 \cdot 3)$ & 382 & $70(18 \cdot 3)$ & 657 & $52(7 \cdot 9)$ & 1316 & $101(7 \cdot 7)$ \\
\hline $50-59$ & 231 & $30(13.0)$ & 340 & $61(17.9)$ & 927 & $45(4.9)$ & 1542 & $108(7 \cdot 0)^{\star}$ \\
\hline $60-69$ & 267 & $33(12 \cdot 4)$ & 387 & $37(9 \cdot 6)$ & 1568 & $56(3 \cdot 6)$ & 2457 & $68(2 \cdot 8)$ \\
\hline$\geqslant 70$ & 331 & $26(7 \cdot 8)$ & 653 & $70(10 \cdot 7)$ & 2487 & $65(2 \cdot 6)$ & 5209 & $151(2.9)$ \\
\hline Total & 1855 & $213(11 \cdot 5)$ & 2999 & $489(16 \cdot 3)$ & 7464 & $327(4 \cdot 4)$ & 13457 & $745(5 \cdot 5) \star$ \\
\hline
\end{tabular}

${ }^{\star} \mathrm{p}<0.05$ men $v$ women

TABLE III-Rate of non-redemption of prescription items issued for men and women for each British National Formulary category

TABLE IV-Rate of non-redemption of prescription items for days of the week

\begin{tabular}{lccccc}
\hline & \multicolumn{2}{c}{ Men } & & \multicolumn{2}{c}{ Women } \\
\cline { 2 - 3 } \cline { 5 - 6 } & $\begin{array}{c}\text { No of } \\
\text { prescriptions } \\
\text { written }\end{array}$ & $\begin{array}{c}\text { No (\%) not } \\
\text { redeemed }\end{array}$ & $\begin{array}{c}\text { po of } \\
\text { prescriptions } \\
\text { written }\end{array}$ & $\begin{array}{c}\text { No (\%) not } \\
\text { redeemed }\end{array}$ \\
\hline Monday & 1556 & $48(3 \cdot 1)$ & & 2896 & $157(5 \cdot 4)^{\star}$ \\
Tuesday & 1622 & $55(3 \cdot 4)$ & & 2931 & $174(5 \cdot 9)^{\star}$ \\
Wednesday & 1450 & $49(3 \cdot 4)$ & & 2695 & $133(4 \cdot 9)^{\star}$ \\
Thursday & 1327 & $71(5 \cdot 4)$ & & 2399 & $105(4 \cdot 4)$ \\
Friday & 1302 & $86(6 \cdot 6)$ & & 2160 & $145(6 \cdot 7)$ \\
Saturday & 101 & $8(7 \cdot 9)$ & & 187 & $13(7 \cdot 0)$ \\
Sunday & 106 & $10(9 \cdot 4)$ & 189 & $18(9 \cdot 5)$ \\
\hline
\end{tabular}

TABLE V-Differences in the rate items between doctors

\begin{tabular}{|c|c|c|}
\hline $\begin{array}{l}\text { Year of } \\
\text { full } \\
\text { registration }\end{array}$ & $\begin{array}{l}\text { Prescriptions } \\
\text { written }\end{array}$ & $\begin{array}{c}\text { No }(\%) \\
\text { not } \\
\text { redeemed }\end{array}$ \\
\hline \multicolumn{3}{|l|}{ Principal } \\
\hline 1972 & 2328 & $104(4 \cdot 5)$ \\
\hline 1973 & 3548 & $160(4 \cdot 5)$ \\
\hline 1969 & 2447 & $154(6 \cdot 3)$ \\
\hline 1980 & 2969 & $142(4 \cdot 8)$ \\
\hline 1978 & 2489 & $92(3 \cdot 7)$ \\
\hline 1983 & 1763 & $82(4 \cdot 7)$ \\
\hline 1982 & 1733 & $91(5 \cdot 2)$ \\
\hline Trainee & 1759 & $112(6 \cdot 4)$ \\
\hline Trainee & 1885 & $135(7 \cdot 2)$ \\
\hline Total & 20921 & $1072(5 \cdot 1)$ \\
\hline
\end{tabular}

those aged 70 years and over (table I). The age and sex distribution of those who received prescriptions during the three month study period, together with the number of prescriptions and the non-redemption rate, are shown in table II. The overall non-redemption rate was significantly higher among women $(p<0.05)$.

Among women the highest rate of non-redemption occurred in those aged 16-29 and fell with increasing age; the pattern was similar when the analysis was performed by prescriptions. Among men, the rate per person was highest in those aged 40-49 years, after which there was a fall. For prescriptions issued to men,

\begin{tabular}{|c|c|c|c|c|}
\hline & \multicolumn{2}{|c|}{$\begin{array}{l}\text { Prescription items } \\
\text { for men }\end{array}$} & \multicolumn{2}{|c|}{$\begin{array}{l}\text { Prescription items } \\
\text { for women }\end{array}$} \\
\hline & Written & $\begin{array}{l}\text { No }(\%) \text { not } \\
\text { redeemed }\end{array}$ & Written & $\begin{array}{l}\text { No }(\%) \text { not } \\
\text { redeemed }\end{array}$ \\
\hline Gastrointestinal & 945 & $37(3.9)$ & 1531 & $57(3 \cdot 7)$ \\
\hline Cardiovascular & 1797 & $52(2.9)$ & 2601 & $84(3 \cdot 2)$ \\
\hline Respiratory & 981 & $48(4.9)$ & 950 & $41(4 \cdot 3)$ \\
\hline Central nervous system & 972 & $36(3 \cdot 7)$ & 2435 & $109(4 \cdot 5)$ \\
\hline Infections & 613 & $29(4 \cdot 7)$ & 1060 & $68(6.4)$ \\
\hline Endocrine & 325 & $14(4 \cdot 3)$ & 1113 & $49(4 \cdot 4)$ \\
\hline \multicolumn{5}{|l|}{ Obstetrics, gynaecology, and } \\
\hline urinary tract disease & 16 & 0 & 512 & $127(24 \cdot 8)$ \\
\hline Malignant disease & 9 & 0 & 69 & $2(2 \cdot 9)$ \\
\hline Nutrition and blood & 104 & $1(1 \cdot 0)$ & 330 & $25(7 \cdot 6)^{\star}$ \\
\hline Musculoskeletal & 531 & $33(6 \cdot 2)$ & 1019 & $54(5 \cdot 3)$ \\
\hline Eye & 207 & $6(2 \cdot 9)$ & 320 & $8(2 \cdot 5)$ \\
\hline Ear, nose, and oropharynx & 129 & $9(7 \cdot 0)$ & 160 & $13(8 \cdot 1)$ \\
\hline Skin & 576 & $31(5 \cdot 4)$ & 902 & $58(6.4)$ \\
\hline Miscellaneous & 259 & $31(12 \cdot 0)$ & 455 & $50(11 \cdot 0)$ \\
\hline Total & 7464 & $327(4 \cdot 4)$ & 13457 & $745(5 \cdot 5)^{\star}$ \\
\hline
\end{tabular}

however, the highest rate of non-redemption occurred among those aged $30-39$ years.

Among women aged 16-39, 110 of 285 (38.6\%) nondispensed prescriptions were written for oral contraceptives. Excluding these from the analysis gave prescription non-redemption rates of $10 \cdot 1 \%$ for those aged $16-29$ and $9 \cdot 5 \%$ for those aged $30-39$.

The numbers of prescriptions not redeemed for each of the major therapeutic groups are shown in table III. Preparations for the ear, nose and oropharynx showed the highest non-redemption rate for both men and women with those for eyes and the cardiovascular system among the lowest.

The non-redemption rate for acute prescribing was $6.9 \%$ in men and $8.7 \%$ in women and for repeat prescribing $3 \cdot 2 \%$ and $4 \cdot 2 \%$. However, acute items accounted for only $24 \cdot 1 \%$ of total prescribing, and thus the bulk of non-redeemed prescriptions were for repeat items.

Prescriptions issued at weekends (table IV) were less likely to be redeemed than those issued during the week, although only $2 \cdot 8 \%$ of prescriptions were issued at weekends.

For individual prescribers the range of non-redemption varied from $3 \cdot 7 \%$ to $7 \cdot 2 \%$ and was highest for trainees (table V). Overall, the non-redemption rate among trainees was significantly higher than that among principals (difference $2.0 \%, 95 \%$ confidence interval $1 \cdot 1 \%$ to $2.9 \%$ ). The rate did not appear to be influenced by the number of prescriptions written or date of admission to the medical register.

The general practice records of all people who did not redeem one or more prescriptions were searched. The records of 171 were unobtainable because they had left the practice or died or for other reasons. It was not possible to identify the patient or prescription in a further 15 cases. Thus $516(73.5 \%)$ patient records were examined, representing 772 prescriptions. Two hundred and eight $(27 \%)$ of these prescriptions were for acute conditions. Altogether $633(82 \%)$ of the prescriptions were for symptomatic conditions with only $39(5 \%)$ for asymptomatic conditions. The remainder were for prophylactic drugs.

In several cases the reasons for non-redemption were obvious. Very recent or imminent bereavement affected three patients, and three others were admitted to hospital within 48 hours of the prescription being issued. A further three patients (one of them on two occasions) awaited a bacteriological report which resulted in a change in the drug required, and two did not redeem a prescription for a drug which had previously caused an adverse reaction. Two patients took their prescriptions to pharmacies outside Tayside (since the pharmacy practice division keeps all prescriptions together in pharmacy specific bundles, these were unobtainable). Two patients indulged in selective non-redemption - that is, they redeemed some but not all of the items on the prescription form, possibly

TABLE VI-Exemption status of patients who redeemed prescriptions and those who did not

\begin{tabular}{lcc}
\hline Exemption category & $\begin{array}{c}\text { Redeemed } \\
\text { prescriptions as } \\
\% \text { of total } \\
\text { redeemed }\end{array}$ & $\begin{array}{c}\text { Non-redeemed } \\
\text { prescriptions as } \\
\% \text { of total not } \\
\text { redeemed }\end{array}$ \\
\hline Women $\geqslant 60$ & $33 \cdot 3$ & $10 \cdot 3$ \\
Men $\geqslant 65$ & $15 \cdot 1$ & $7 \cdot 2$ \\
Children $<16$ & $10 \cdot 5$ & $5 \cdot 6$ \\
In full time education $<19$ & $1 \cdot 3$ & $0 \cdot 4$ \\
Income support or family credit & $2 \cdot 1$ & $2 \cdot 7$ \\
Health board certification (including & & \\
pregnancy and oral contraceptive) & $8 \cdot 7$ & $19 \cdot 1$ \\
Prepayment certificate & $7 \cdot 2$ & $21 \cdot 2$ \\
DHSS exemption certificate & $4 \cdot 1$ & Not known \\
War service pensioner & $0 \cdot 2$ & Not known \\
Other (exemption claimed but reason & & \\
$\quad$ unclear) & $0 \cdot 1$ & Not innown \\
Not exempt & $17 \cdot 4$ & $33 \cdot 1$ \\
\hline
\end{tabular}


because some items were available more cheaply over the counter. A further eight patients had other sensible reasons for not redeeming their prescriptions. In most cases, however, no reason for primary non-compliance could be ascertained.

It was possible to infer the social class for 421 patients. Non-redemption by social class seemed to reflect the social class distribution of the practice, with the highest proportion of non-redemption in social class III (49\%) which represented $51 \%$ of the practice population. The exemption status of patients who redeemed or did not redeem prescriptions is given in table VI. A smaller proportion of patients who redeemed prescriptions were judged to be exempt from payment than among those who did not redeem prescriptions. Nevertheless, it was not possible to determine from the case records whether patients held a Department of Health and Social Security exemption certificate or whether they were a war service pensioner. Of the 45 patients with known exemption status 44 were judged to be exempt by case note searching, compared with 45 by prescription self certification. In 38 cases the reason for exemption was identical by the two methods although in six the reason was different.

\section{Discussion}

This study shows the wide variety of factors associated with the non-redemption of prescriptions. Age seems to be one of the most important associations. Whether this is due to age itself or to the fact that exemption status is linked to age is difficult to discern. Despite the limitations of trying to infer exemption status from case records, it would appear that about one third of patients who fail to redeem their prescriptions have to pay prescription charges compared with $17 \%$ of those who do redeem prescriptions. Further work is required to clarify the possible causal association between exemption status and prescription redemption.

Although the lowest rates of non-redemption were in patients who were exempt from prescription charges, $62 \%$ of all non-redemption was found in this groupprobably because these patients account for the bulk of prescribing. Although the distribution of non-redemption followed the general social class distribution of the population, we could not determine the overall use of prescription drugs in each social class; thus the results should be interpreted with caution.

FACTORS INFLUENCING NON-REDEMPTION

Women were less likely than men to redeem prescriptions, but most of this difference seems to be accounted for by oral contraception, iron, and treatments for vulval or vaginal conditions. Possibly patients keep prescriptions for some of these agents until they are required rather than redeem them immediately. Had we collected dispensed prescriptions for longer this might have been apparent. When prescriptions for these drugs were omitted from the analysis, $14.2 \%$ of women failed to have prescriptions dispensed compared with $11.5 \%$ of men.

The rate of prescription non-redemption seemed to bear some relation to the prescribing doctor, being lowest in partners and highest in trainees. This did not appear to be related to time from registration or to differences in the rates of prescribing between doctors. It might have been due to more subtle factors such as the patient's confidence in the doctor, and this factor requires further study. Most of the non-redeemed prescriptions were for repeat items and symptomatic conditions, a trend that has been reported by others. ${ }^{56}$

A rather surprising finding was that prescriptions issued at the weekend, presumably after emergency calls, were the least likely to be redeemed. Intuitively one would think that these patients would be the most likely to wish their symptoms to be treated and thus the most likely to redeem their prescriptions. On the other hand, they might be the most disabled patients and be the least able to reach a pharmacy.

There are other possible explanations why patients may not redeem prescriptions. Patients may not, for example, redeem a prescription for a drug when they have previously had an adverse reaction to it or when symptoms resolve either spontaneously or in response to emergency supplies or "starter packs" given by the general practitioners. Such reasons can be discerned only by prospective studies or by interviewing patients who do not redeem prescriptions.

Our overall rates of non-redemption $(14.5 \%$ of patients and $5 \cdot 2 \%$ of prescriptions) were lower than those found by others, ${ }^{46}$ probably because of differences such as sample size, timespan of data collection, and population demographics between the studies. For example, Begg used only prescriptions issued over one month'; Waters et al examined prescribing in a mining town ${ }^{4}$; and Rashid used prescriptions issued over three days. ${ }^{6}$

Our study was carried out in only one health centre and thus may not be generally representative of prescribing and redemption. In particular, the health centre has operated a practice formulary since 1985 . This limits the range of drugs prescribed in comparison with other Tayside practices and results in the practice being low in cost per patient but high in the number of items issued per patient.

\section{ACCURACY OF PRESCRIBING DATA}

Our findings do, however, cast doubt on the accuracy of the drug prescribing data often used in observational drug use and drug safety studies. Data on drugs prescribed, rather than dispensed, can lead to the misclassification of drug exposure; in certain patient groups this misclassification may be considerable. This limits the usefulness of databases that record prescribing rather than dispensing in pharmacoepidemiological research ${ }^{8}$ as misclassification influences both the magnitude and direction of the resulting bias. ${ }^{9}$

The factors associated with prescription nonredemption are multifactorial. Perhaps the cameo of a person least likely to redeem a prescription is a middle aged woman, not exempt from prescription charges, who has a symptomatic condition requiring an acute prescription that is issued by a trainee general practitioner on a Sunday.

We gratefully acknowledge the help and cooperation of our other general practice colleagues at Carnoustie Health Centre, Drs F R Crosby, E McNaughton, H Leslie, P W Thornton, LJ Morton, and A M Easton.

1 Feely M, Pullar T. Therapeutic compliance: myths and misunderstandings. Geriatric Medicine 1989:June: 14-8.

2 Col N, Fanale JE, Knonholm P. The role of medication noncompliance and adverse drug reactions in hospitalizations of the elderly. Arch Intern Med 1990;150:841-5.

3 Wiseman IC, Miller R. Quantifying non-compliance in patients receiving digoxin - a pharmacokinetic approach. S Afr Med f 1991;79:155-7.

4 Waters WHR, Gould NV, Lunn JE. Undispensed prescriptions in a mining practice. $B M F$ 1976;1:1062-3.

5 Begg D. Do patients cash prescriptions? An audit in one practice. $f R$ Coll Gen Pract 1984;34:272-4.

6 Rashid A. Do patients cash prescriptions? BMF 1982;284:24-6.

Wonnacott TH, Wonnacott RJ. In: Introductory statistics. 3rd ed. New York: John Wiley, 1977:223.

8 Jick $H$, Jick S, Derby LE. Validation of information recorded on general practitioner based computerised data resource in the United Kingdom. BMF 1991;302:766-8.

9 Graham DJ, Smith CR. Misclassification in epidemiologic studies of adverse drug reactions using large managerial databases. Am $f$ Prev Med 1988; 4(suppl):15-24

(Accepted 12 August 1993) 